\title{
ANKLE BRACHIAL INDEX (ABI) PADA PENDERITA DM TIPE 2 DI PUSKESMAS KABUPATEN LAMPUNG UTARA
}

\author{
Imam Budi Pratomo *, Heni Apriyani* \\ *Prodi Diploma III Keperawatan Kotabumi Poltekkes Tanjungkarang
}

\begin{abstract}
International Diabetes Federation (IDF) menyatakan bahwa lebih dari 371 juta orang di dunia yang berumur 20-79 tahun menderita diabetes. Indonesia merupakan negara urutan ke-7 dengan prevalensi diabetes tertinggi di dunia. Penelitian ini bertujuan mengetahui gambaran nilai Ankle Brachial Index (ABI) penderita DM tipe 2 di Puskesmas Kabupaten Lampung Utara. Penelitian dengan rancangan deskriptif dilakukan selama 2 minggu. Penelitian melibatkan 98 responden penderita diabetes mellitus tipe 2 yang terdaftar di Puskesmas Kotabumi Kabupaten Lampung Utara. Teknik pengambilan sampel adalah total populasi. Hasil penelitian menunjukkan bahwa karakteristik penderita DM tipe 2 di Puskesmas Kotabumi yaitu perempuan sebanyak 62 orang (63,3 \%), laki-laki 36 orang (36,7\%), dan responden berusia $>60$ tahun sebanyak 37 orang $(37,9 \%)$. Sedangkan klasifikasi nilai ABI menunjukkan bahwa 77,5\% responden adalah normal, sedangkan 22,5\% responden adalah borderline perfusion.Saran bagi Puskesmas diharapkan dapat menerapkan pemeriksaan ABI terhadap penderita DM guna diagnosis awal sirkulasi bagi penderita DM. Pada pasien yang memiliki ABI nornal diharapkan untuk dilakukan penyuluhan tentang diet dan aktivitas guna mempertahankan bahkan meningkatkan kualitas hidup penderita diabetes. Pasien dengan ABI borderline perfusion, diharapkan untuk dilakukan penyuluhan tentang diet, pengaturan aktivitas, konsultasi gizi, dan terapi aktivitas fisik (olahraga) guna mengurangi / mencegah komplikasi lebih lanjut.
\end{abstract}

Kata kunci: diabetes mellitus, ankle branchial indeks

\section{LATAR BELAKANG}

Penyakit tidak menular (PTM) seperti penyakit kardiovaskuler dan degeneratif saat ini sudah menjadi masalah kesehatan masyarakat, baik secara global maupun lokal. Badan kesehatan dunia (WHO) tahun 2010 melaporkan bahwa $60 \%$ penyebab kematian semua umur di dunia adalah karena penyakit tidak menular. Diabetes Melitus (DM) merupakan salah satu penyakit tidak menular yang menyita banyak perhatian (Kemenkes, 2013). International Diabetes Federation (IDF) menyatakan bahwa lebih dari 371 juta orang di dunia yang berumur 20-79 tahun menderita diabetes. Indonesia merupakan negara urutan ke-7 dengan prevalensi diabetes tertinggi (Kemenkes, 2013).

Ada empat klasifikasi klinis diabetes melitus yang utama, yaitu: diabetes melitus tipe 1 dan 2 , diabetes gestasional, dan diabetes melitus yang berhubungan dengan keadaan atau sindroma lainnya (Price \& Wilson, 2006). Diabetes Melitus tipe 2 menduduki peringkat ke-6 sebagai penyebab kematian. Sekitar 1,3 juta orang meninggal akibat diabetes tipe 2 dan $4 \%$ meninggal sebelum usia 70 tahun. (Kemenkes, 2014).

Berdasarkan hasil Riset Kesehatan Dasar (Riskesdas) tahun 2013, di Indonesia terjadi peningkatan DM tipe 2 dari $1,1 \%$ pada tahun 2007 menjadi 2,1 \% dari jumlah penduduk pada tahun 2013. Persentase penderita DM tipe 2 di Provinsi Lampung sejumlah 1,5\% per 100.000 penduduk (Kemenkes, 2013). Jumlah penderita DM tipe 2 di Kabupaten Lampung Utara tahun 2012 sebanyak 501 kasus baru dan tahun 2013 sebanyak 561 kasus baru (Dinas Kesehatan Kabupaten Lampung Utara, 2013).

Angka kematian yang berkaitan dengan komplikasi akut penderita DM tipe 2 di beberapa negara maju tampak terus menurun, tetapi kematian akibat komplikasi kronik berupa penyakit kardiovaskuler dan renal mengalami kenaikan yang cukup mengkhawatirkan (Smeltzer \& Bare, 2008). Sebanyak $15 \%$ 
komplikasi yang terjadi pada setiap penderita diabetes tipe 2 adalah komplikasi pembuluh perifer pada kaki yang sering disebut diabetic foot atau kaki diabetes (Widianti \& Proverawati, 2010).

Penyakit oklusif arteri yang parah pada ekstremitas bawah berupa peripheral artery disease (PAD). Penderita DM tipe 2 berisiko mengalami penyakit oklusif arteri perifer dua hingga tiga kali lipat dibandingkan non DM. Penderita dengan gangguan pada vaskuler perifer akan mengalami berkurangnya denyut nadi perifer dan klaudikasi intermiten (Ernawati, 2013).

Salah satu cara mendeteksi PAD secara dini dapat dilakukan dengan pemeriksaan sirkulasi melalui perhitungan nilai Ankle Brachial Index (ABI), dengan cara membandingkan tekanan darah sistolik pada pergelangan kaki dan lengan (Dillon, 2007:536). Ada 4 interpretasi nilai ABI yaitu, normal $(\geq 0,9-1,3)$, borderline $(\geq 0,6-0,8)$, iskemia berat $(\leq 0,5)$, dan iskemia kaki kritis $(\leq 0,4)$ (Bryant \& Nix, 2006).

Penderita DM tipe 2 di Puskesmas Kotabumi II Kecamatan Kotabumi Selatan Kabupaten Lampung Utara terus mengalami peningkatan dari tahun 2012 sejumlah 90 penderita menjadi 98 penderita pada tahun 2013. Hal ini berarti $20 \%$ penderita DM tipe 2 di Kabupaten Lampung Utara terdapat di Puskesmas Kotabumi II dan $80 \%$ sisanya tersebar di 25 Puskesmas di Kabupaten Lampung Utara. Pemeriksaan ABI untuk mendeteksi PAD pada penderita DM tipe 2 di Puskesmas Kotabumi II belum pernah dilakukan, padahal penderita DM berisiko mengalami dua kali lipat mengalami penyakit arteri perifer.

\section{METODE}

Desain penelitian ini adalah penelitian deskriptif) dengan tujuan ingin mencari gambaran nilai ankle brachial index (ABI) penderita DM tipe 2 di Puskesmas Kabupaten Lampung Utara.
Teknik pengambilan sampel yang digunakan adalah total sampling dengan jumlah sampel sebanyak 98 responden. Pengumpulan data dilakukann dengan cara mengunjugi rumah responden atau responden berkunjung ke Puskesmas. Alat yang digunakan dalam penelitian adalah tensimeter digital dan lembar observasi untuk mencatat tekanan darah responden. Sebelum pengukuran tekanan darah dilakukan, responden diminta berbaring pada posisi supinasi kurang lebih selama 10 menit, kemudian peneliti mengukur tekanan darah responden pada lengan (brachial) kanan kemudian pada lengan kiri menggunakan tensimeter digital dan mencatat tekan sistolik pada masingmasing lengan. Setelah itu, peneliti mengukur tekanan darah pada kaki (ankle) kanan kemudian kaki kiri menggunakan tensimeter digital dan mencatat tekan sistolik pada masing-masing kaki. Rumus penghitungan ABI yaitu membandingkan tekanan sistolik membagi tekanan sistolik tertinggi dari kedua ekstremitas pada area ankle dengan sistol tertinggi pada area brachial.

Analisis univariat digunakan untuk mengetahui distribusi frekuensi pada karakteristik responden, yaitu jenis kelamin, usia dan penghitungan ABI.

\section{HASIL}

Tabel 1: Distribusi Responden Berdasarkan Jenis Kelamin

\begin{tabular}{lcc}
\hline \multicolumn{1}{c}{ Jenis Kelamin } & $\mathrm{f}$ & $\%$ \\
\hline Laki-laki & 36 & 36,7 \\
\hline Perempuan & 62 & 63,7 \\
\hline \multicolumn{1}{c}{ Jumlah } & 98 & 100 \\
\hline
\end{tabular}

Berdasarkan tabel di atas responden yang berjenis kelamin perempuan sebanyak 62 orang $(63,7 \%)$. 
Tabel 2: Distribusi Responden Berdasarkan Usia.

\begin{tabular}{|c|c|c|}
\hline Usia & $\mathrm{f}$ & $\%$ \\
\hline $40-45$ & 2 & 2,0 \\
\hline $46-50$ & 16 & 16,3 \\
\hline $51-55$ & 25 & 25,5 \\
\hline $56-60$ & 18 & 18,3 \\
\hline$>60$ & 37 & 37,9 \\
\hline Jumlah & 98 & 100 \\
\hline
\end{tabular}

Berdasarkan tabel di atas 37,9\% responden berusia lebih dari 60 tahun.

Tabel 3: Distribusi ABI Responden Berdasarkan Jenis Kelamin dan Usia

\begin{tabular}{ccccccc}
\hline \multirow{2}{*}{ Umur } & \multicolumn{2}{c}{ Borderline } & \multicolumn{2}{c}{ Normal } & \multicolumn{2}{c}{ Total } \\
\cline { 2 - 7 } & $\mathrm{f}$ & $\%$ & $\mathrm{f}$ & $\%$ & $\mathrm{f}$ & $\%$ \\
\hline $40-45$ & 0 & 0 & 2 & 100 & 2 & 100 \\
\hline $46-50$ & 4 & 25 & 12 & 75 & 16 & 100 \\
\hline $51-55$ & 6 & 24 & 19 & 76 & 25 & 100 \\
\hline $56-60$ & 5 & 27,8 & 13 & 72,2 & 18 & 100 \\
\hline$>60$ & 7 & 18,9 & 30 & 81 & 37 & 100 \\
\hline Jumlah & 22 & 22,5 & 76 & 77,5 & 98 & 100 \\
\hline
\end{tabular}

Berdasarkan tabel di atas, borderline perfusion pada kelompok umur 56-60 tahun sebanyak 5 dari 18 orang atau sebanyak $27,8 \%$.

Tabel 4: Nilai ABI Pasien DM Tipe 2

\begin{tabular}{lcc}
\hline \multicolumn{1}{c}{ Klasifikasi } & $\mathrm{f}$ & $\%$ \\
\hline Normal & 76 & 77,5 \\
\hline Borderline Perfusion & 22 & 22,5 \\
\hline Iskemia Berat & 0 & 0,0 \\
\hline Iskemia Kaki Kritis & 0 & 0,0 \\
\hline \multicolumn{1}{c}{ Jumlah } & 98 & 100 \\
\hline
\end{tabular}

Tabel di atas menunjukkan, bahwa 76 responden memiliki nilai ABI normal, atau sebanyak $77,5 \%$.

\section{PEMBAHASAN}

\section{Nilai ABI normal}

Berdasarkan hasil penelitian didapatkan bahwa 76 responden $(77,5 \%)$ memiliki ABI normal dengan jumlah terbanyak pada perempuan yaitu 49 orang $(79,0 \%)$. Berdasarkan tabel 6, nilai ABI dengan interpretasi normal pada kelompok umur > 60 tahun sebanyak 81,0 \% . Hal ini terjadi karena penderita DM di Puskesmas Kotabumi II rutin melakukan kontrol dan terapi seperti senam DM yang merupakan salah satu program Puskesmas Kotabumi II untuk meningkatkan kesehatan diabetisi. Hal ini terbukti dari absensi kehadiran peserta PPDM yang sebagian besar dihadiri oleh perempuan.

Hal ini sejalan dengan teori yang menyatakan bahwa interpretasi $\mathrm{ABI}$ normal berarti darah masih bersirkulasi dengan baik, tanpa adanya obstruksi yang bermakna pada pembuluh darah perifer, sehingga kebutuhan nutrisi dan oksigen pada ekstremitas bawah masih dapat terpenuhi dengan baik. Senam DM merupakan salah satu bentuk latihan fisik. Efek latihan adalah menurunkan kadar glukosa darah, memperbaiki sirkulasi darah, meningkatkan pengambilan glukosa oleh otot, dan memperbaiki pemakaian insulin (Smeltzer \& Bare, 2008). Penderita DM yang tergolong usia pertengahan / middle age (45 - 49 tahun), keadaan pembuluh darah relatif masih baik, namun perlu pemantauan untuk mengantisipasi terjadinya PAD (Mansjoer,2005).

\section{Borderline perfusion}

Nilai ABI dalam rentang 0,6 sampai 0,8 merupakan borderline perfusion. Berdasarkan tabel 7, sebanyak 22,5\% penderita DM tipe 2 di Puskesmas Kotabumi II memiliki interpretasi ABI borderline perfusion dan menurut tabel 5 , terdapat 25,0 \% laki-laki dengan interpretasi ABI borderline perfusion. Pasien DM dengan interpretasi borderline perfusion berisiko dua hingga tiga kali lipat mengalami sumbatan pembuluh darah perifer berupa PAD dibandingkan pasien non DM (Ernawati, 2013). Faktor resiko seperti kebiasaan merokok dan minuman beralkohol yang biasanya dimiliki oleh laki-laki serta obesitas akan meningkatkan resiko terjadinya PAD (Braynt \& Nix, 2006). 
Pada pasien DM terjadi perubahan elastisitas kapiler pembuluh darah, penebalan dinding pembuluh darah, dan pembentukan plak atau trombus yang menyebabkan vaskularisasi ke perifer terhambat. Keadaan ini menyebabkan pasien DM cenderung memiliki ABI yang lebih rendah daripada rentang normal (Ernawati, 2013).

Prevalensi PAD pada penderita DM tipe 2 dilaporkan terjadi sebesar 20,5\% pada usia 40-59 tahun, 48,3\% usia 60-69 tahun, dan $31,2 \%$ usia 70-79 tahun (Jaff, 2004 dalam Chaniago, 2007). Berdasarkan tabel 6 didapatkan bahwa kelompok umur 56 - 60 tahun merupakan kelompok umur terbanyak dengan ABI borderline perfusion sebanyak $27,8 \%$.

Proses penuaan yang mengakibatkan perubahan dinding pembuluh darah sehingga mempengaruhi transportasi oksigen dan nutrisi ke jaringan. Lapisan intima menebal sebagai akibat proliferasi seluler dan fibrosis. Serabut di lapisan media mengalami kalsifikasi, tipis dan terpotong, serta kolagen yang menumpuk di lapisan intima dan media. Perubahan tersebut menyebabkan kekakuan pembuluh darah, yang mengakibatkan peningkatan tekanan pembuluh perifer, ganguan aliran darah, dan peningkatan kerja ventrikel kiri (Smeltzer \& Bare, 2008).

\section{Iskemia berat}

Hasil penelitian tidak menunjukkan adanya penderita DM tipe 2 di Puskesmas Kotabumi II yang memiliki interpretasi $\mathrm{ABI}$ iskemia berat..

Kondisi iskemia berat dengan nilai $\mathrm{ABI} \leq 0,5$ terjadi akibat buruknya perfusi perifer karena oklusi yang mulai memanjang sehingga denyut jantung dan tekanan arteri menurun karena adanya plak dan sering terjadi aterotrombosis atau tromboemboli. Hal ini mengakibatkan hipoksia jaringan sehingga mengakibatkan iskemia pada kaki dan bila terdapat luka, maka penyembuhan luka sulit kecuali dilakukan revaskularisasi (Sudoyo, 2007). Iskemia berat dapat diklasifikasikan dengan "6 P", yaitu: pulselessness, pain, pallor, poikilothermy

(coldness), parastesia, paralysis.

\section{Iskemia kaki kritis}

Nilai $\mathrm{ABI} \leq 0,4$ mengartikan bahwa telah terjadi iskemia pada kaki yang kritis. Hal ini merupakan kondisi klimaks dari iskemia berat yang dimanifestasikan dengan terjadinya ulserasi dan gangren. Gangren yang terjadi menunjukkan adanya kematian jaringan atau nekrosis. Gangren dibedakan menjadi 2 yaitu gangren kering yang disebabkan berhenti totalnya aliran darah dengan nekrosis pada seluruh bagian dan gangren basah jika obstruksinya tidak total sehingga daerah nekrosis.

\section{KESIMPULAN}

Berdasarkan penelitian diatas, dapat disimpulkan bahwa Sebagian besar kelompok umur 56-60 tahun memiliki interpretasi borderline perfusion sebanyak 5 orang $(27,8 \%)$. Sebagian besar penderita DM tipe 2 memiliki interpretasi nilai $\mathrm{ABI}$ normal, yaitu sebanyak 76 orang $(77,5 \%)$.

Berkaitan dengan simpulan hasil penelitian diatas, ada beberapa hal yang dapat disarankan untuk pengembangan dari hasil penelitian ini yaitu Diharapkan dapat menerapkan pemeriksaan ABI terhadap penderita DM guna diagnosis awal sirkulasi bagi penderita DM. Pada pasien yang memiliki ABI nornal diharapkan untuk dilakukan penyuluhan tentang diet dan aktivitas guna mempertahankan bahkan meningkatkan kualitas hidup penderita diabetes. Pasien dengan ABI borderline perfusion, diharapkan untuk dilakukan penyuluhan tentang diet, pengaturan aktivitas, konsultasi gizi, dan terapi aktivitas fisik (olahraga) guna mengurangi / mencegah komplikasi lebih lanjut. 
DAFTAR PUSTAKA

Bryant, R.A., Nix, DP. (2006). Acute \& Chronic Wounds: Current Management Concepts $3^{\text {rd }}$ edition. St Louis: Mosby.

Dinas Kesehatan Kabupaten Lampung Utara. (2013). Profil Kesehatan Kabupaten Lampung Utara Tahun 2013. Kotabumi: Dinkes Lampung Utara.

Ernawati. (2013). Penatalaksanaan Keperawatan Diabetes Melitus Terpadu: Dengan Penerapan Teori Self Care Orem. Jakarta: Mitra Wacana Media.

Kemenkes. (28 September 2013). Diabetes Melitus Penyebab Kematian Nomor 6 di Dunia: Kemenkes Tawarkan Solusi CERDIK Melalui Posbindu]. Diakses dari: (http://depkes.go.id/ index.php?vw $=2 \& p g=\quad$ SearchPage $\& \mathrm{kyw}=\mathrm{CERDIK})$.

Kemenkes RI. (2014). Laporan Riset Kesehatan Dasar (RISKESDAS) 2013. Jakarta: Kemenkes RI.

Price, S.A., Wilson, L.M. (2006). Patofisiologi: Konsep Klinis ProsesProses Penyakit edisi 6 vol 1. Jakarta: EGC.

Smeltzer, S.C., Bare, B.G. (2008). Buku Ajar Keperawatan Medikal-Bedah Brunner \& Suddarth Vol. 2. Jakarta: EGC.

Sudoyo, A.W. dkk. (2007). Buku Ajar Ilmu Penyakit Dalam Jilid 3 Edisi 4, Jakarta: Pusat Penerbitan IPD FKUI..

Widianti, A.T., Proverawati, A. (2010). Senam Kesehatan:Aplikasi Senam Untuk Kesehatan, Yogyakarta: Nuha Medika. 